\title{
NICKNAMING AS NOMINATION CRIME: BREAKING THE RULES OF CONVENTIONAL ANTHROPONYMIC NAME-GIVING
}

\author{
Anna Tsepkova \\ Novosibirsk State Pedagogical University, Russia
}

\begin{abstract}
The paper analyzes contemporary nicknaming practices in Novosibirsk region (Russia) as a profaning type of nomination. Looking into nicknaming practices as representing the category of the profane, I apply the cognitive metaphor "nicknaming is a nomination crime", according to which nicknaming is opposed to baptizing as a sacred act, preceded by the careful choice of a name.

In this paper I argue that any anthroponymic nickname, regardless of its motivation and evaluative potential, is profane to a certain degree. Thus, the following features of the profane are traced in nicknames: a) profaning the officially established rules (level of status); b) familiarity, breaking the hierarchy, criticizing, evaluating through mockery and laughter (level of function and connotation); c) profaning individuals (their official names and personal qualities), revealing the secret (hidden, sacred) meaning; exaggerating, contradicting, denying reality, turning it upside down (level of meaning and motivation); d) profaning nickname givers (self-profaning).

Further on, the paper considers Russian micro-social anthroponymic nicknames, varying in their functional, connotative and motivational properties, according to the degree of profanity.
\end{abstract}

Keywords: Russian nicknames, unconventional anthroponym, the profane, the carnivalesque, motivation.

\section{Introduction. Resources, objectives and methods of research}

The present research is the case study of nicknaming practices of Novosibirsk and Novosibirsk region (Russia). Nicknames collected for this research were reported by school, college and university students, who took part in the survey in 2014-2017.

The aim of the paper is to analyze contemporary anthroponymic nicknames and nicknaming acts from the point of view of their profaning potential. Thus, we pursue the following objectives:

a) to overview the category of the profane in its connection with the theory of carnivalization;

b) to trace the features of the profane in nicknames as a type of nomination, with respect to their status, functions and connotation;

c) to distinguish between profane and non-profane nicknames;

d) to point out the layers of the profane in nicknames; 
e) to discuss the degrees of profanity in nicknames of different motivational types.

The methods of research include quantitative and interpretational analyses of the data retrieved from questionnaires. The subjects chosen for the survey represent the groups which have been universally considered the most active users of nicknames (Morgan et al. 1979, Klerk et al. 1997, Felecan 2014: 66). The total number of respondents is 621 students of educational institutions from Novosibirsk and Novosibirsk region (ref. Table 1).

Table 1.Sample distribution by institution (2014-2017)

\begin{tabular}{|l|c|}
\hline Institution & Number of respondents \\
\hline Schools & 321 \\
\hline Novosibirsk State Pedagogical University & 56 \\
\hline Novosibirsk State Technical University & 65 \\
\hline Other institutions of higher education & 6 \\
\hline Novosibirsk colleges of vocational training & 173 \\
\hline Total number of respondents & 621 \\
\hline
\end{tabular}

Table 2 below represents the sample distribution by gender. Gender ratio shows that the difference between the male and female subsamples is not significant $(\chi 2=3.3$; $\mathrm{p} \leq 0,05)$.

Table 2. Sample distribution by gender

\begin{tabular}{|l|c|c|c|}
\hline \multirow{2}{*}{ Institution } & \multicolumn{3}{|c|}{ Gender } \\
\cline { 2 - 4 } & Male & Female & Not specified \\
\hline School & 149 & 165 & 7 \\
\hline Novosibirsk colleges of vocational training & 124 & 57 & 8 \\
\hline Novosibirsk State Pedagogical University & 4 & 38 & - \\
\hline Novosibirsk State Technical University & 41 & 24 & - \\
\hline Other institutions of higher education & 0 & 3 & 1 \\
\hline Total number of respondents & 318 & 287 & 16 \\
\hline
\end{tabular}

Table 3 below represents the sample distribution by age, showing the average age of the subjects, the age range and the biggest age groups in school, college and university subsamples.

Table 3. Sample distribution by age

\begin{tabular}{|l|c|c|c|}
\hline \multirow{2}{*}{ Institution } & \multicolumn{3}{|c|}{ Age } \\
\cline { 2 - 4 } & $\begin{array}{c}\text { Biggest age group / } \\
\text { group size }\end{array}$ & Average & Range \\
\hline School & $11 / 61$ & 13.5 & $10-18$ \\
\hline Novosibirsk colleges of vocational training & $17 / 59$ & 16.7 & $15-21$ \\
\hline Novosibirsk institutions of higher education & $20 / 27$ & 19.5 & $17-27$ \\
\hline
\end{tabular}




\section{Categories of the profane and the carnivalesque}

\section{The notion of the profane}

Upon looking into nicknaming practices as representing the category of the profane, I apply the cognitive metaphor "nicknaming is a nomination crime", according to which nicknaming is opposed to baptizing as a sacred act, preceded by the careful choice of a name. As D. Felecan points out, "naming by nicknames is an act that may be seen as profane (as compared to the religiousness entailed by the actual naming), as anonymous and as subversive" (Felecan 2009: 66).

When analyzing the category of the profane the following dictionaries were used: Cambridge Dictionary.org. (further referred to as CAD) Merriam-Webster.com (further referred to as MWD), Oxford Learner's Dictionaries.com (further referred to as OLD).

Thus, the following features of the category, which are relevant for our analysis, were pointed out:

1) opposed to sacred as having or showing disrespect for God/a god, holy things, religion (CAD, MWD, OLD);

2) secular, not connected with religion or holy things (OLD), relating to ordinary life: not religious or spiritual (MWD). The meaning develops from the etymology of the word profane, which, according to (OLD), comes "from Old French prophane, from Latin profanus 'outside the temple, not sacred', from pro- (from Latin pro 'before') + fanum 'temple'.

3) expressed through language, desecrating or debasing "by a wrong, unworthy, or vulgar use" (MWD).

The term "profanity" can be applied to a person's non-verbal or verbal behavior (or particular vocabulary s/he uses), representing the category of the profane in one of the meanings mentioned above. The subject (the source) of profanity is referred to as the profaner (MWD).

Maurice Hunt highlights the two first meanings in his article: "Profane', however, covers a broad band of meaning. At one extreme, it stands for obscene blasphemy, religious heresy; at the other, it can mean something nonreligious in subject matter, form, or use - something worldly, in other words. In between these extremes, a perplexing number of shades of meaning appear" (Hunt 2008: 175).

Extending the metaphor of nomination crime, I would like to trace those shades viewed through the prism of the concept of carnivalization.

\section{The profane as a part of carnival and the notion of carnivalization}

The analysis of the profane as part of carnivalization is based on the theory of the carnivalesque, worked out by M.M. Bakhtin (Bakhtin 1990) and developed by D.S. Likhachev, A.M. Panchenko and N.V. Ponyrko (Likhachev et al. 1984). According to these authors as well as the Literary Encyclopedic Dictionary (1987), the profane expresses itself in:

1) protest through parody of something serious, official, established, static; 
2) familiarity, breaking the hierarchy;

3) criticizing, evaluating through mockery and laughter;

4) revealing the secret (hidden, sacred) meaning;

5) exaggerating, contradicting, denying reality, turning it upside down.

It is important to emphasize, that the above-mentioned features are interlaced and interdependent, so it is impossible to characterize one feature without touching upon the others.

\section{Nicknaming as nomination crime: profaning the conventions of official nomination}

The profane as part of the carnival is expressed in protest through the parody of something serious, established, static, such as traditional, dogmatic rules, norms etc., rebelling against the officially accepted, ready-made aspects of life.

A. Ross (2013: 356) points out that "in the space of the profane, ordinary things and events happen in an unremarkable way. In contrast, the space of the sacred is one in which everything that occurs is marked as significant and assimilated into the ritual pattern and thus guarded". This aspect of the profane is featured in nicknames through profaning the act of baptism or legal act of name-giving by violating the rules of the nomination act itself - breaking or intruding into the sacred and solemn ritual or taking the privilege of bestowing a name, which is corrupt to a certain degree, depending on the type of motivation and connotation.

According to M. Bakhtin, an important tool of the carnivalesque in general and parody in particular is carnival laughter, as it displays neglecting rules, freedom from rules and symbolizes fearlessness (Khalizev 2005: 85). In this respect, nicknames are viewed as tools of the profane, used for self-expression to show off bravery and freedom from rules (both linguistic and extralinguistic rules of behavior), which results in the nickname giver's intention to provoke laughter by means of public mockery at a person and at the nomination act as well.

The main aspects of nicknaming as nomination crime from the viewpoint of status in the anthroponymic system are shown in Table 4 below.

Table 4. Breaking the conventions of official anthroponymic nomination (official names vs nicknames)

\begin{tabular}{|l|l|l|}
\hline Aspect of nomination & Official name & Nickname \\
\hline 1. Choice of a name & careful, prescriptive & spontaneous \\
\hline 2. Nomenclature & limited, static & not limited, dynamic \\
\hline 3. Name givers & limited & not limited \\
\hline 4. Functions & $\begin{array}{l}\text { limited number of func- } \\
\text { tions (identification) }\end{array}$ & $\begin{array}{l}\text { unlimited functions; } \\
\text { multifunctionality of nicknames (diffe- } \\
\text { rent combinations of functions for one } \\
\text { nickname) }\end{array}$ \\
\hline
\end{tabular}




\begin{tabular}{|l|l|l|}
\hline Aspect of nomination & Official name & Nickname \\
\hline $\begin{array}{l}\text { 5. Motivation (reason } \\
\text { for choosing a particular } \\
\text { name) }\end{array}$ & $\begin{array}{l}\text { - aesthetic or phonetic; } \\
\text { - etymological } \\
\text { - commemorative/ } \\
\text { hereditary } \\
\text { (Chernobrov 2006: } \\
183-184)\end{array}$ & depends on the functions \\
\hline 6. Meaning/etymology & not clear/not obvious ${ }^{1}$ & $\begin{array}{l}\text { depends on the type of nickname, but } \\
\text { the majority of nicknames tend to be } \\
\text { meaningful }\end{array}$ \\
\hline
\end{tabular}

1 Though there are cases of transparent etymology (Roza 'Rose', Vera 'Faith', Nadezhda 'Hope', Lyubov 'Love', Lev 'Leo' etc.), such names are less popular in Russian linguoculture than etymologically non-transparent ones.

To describe the notion of nickname in Russian linguoculture, I turn to the opinion of the subjects who took part in the questionnaire survey in 2014-2017. Given below is the notion of nickname as viewed by young people from Novosibirsk and Novosibirsk region.

Firstly, attention should be paid to the problem of terminology. In contemporary Russian linguoculture the phenomenon of nicknaming is known by the following terms: прозвище (prozvishshe), кличка (klichka), погоняло (pogonyalo), позыьвной (pozyvnoy), nрuщеn (pritsep), погремуха (pogremukha).

In Russian onomastics using the word nрозвище (prozvishshe) as a term was criticized due to the fact that it was considered vague and charged with connotations, as it sounded colloquial and non-scientific ${ }^{1}$ (Ushakov 1978: 148-149). However, no neutral synonym was introduced and this word has been in frequent circulation in onomastic research. Since frequency leads to neutralization of connotations, native speakers have been developing other colloquial synonyms for this term, which would emphasize the properties of a nickname as an unconventional type of anthroponymic nomination characteristic of informal colloquial style.

Let us consider the colloquial synonyms for prozvishshe mentioned in the questionnaires, when the subjects were asked to give the definition of this term:

1) klichka (or klikukha as its more colloquial variant). According to (Podolskaya 1988: 65) the word is used: 1 ) as a pet name for an animal/a zoonym; 2) a name given and used as a means of conspiracy by members of some secret/illegal organization, e.g. among revolutionaries in pre-Soviet Russia; 3 ) a colloquial variant of an anthroponymic nickname;

2) pogonyalo (or pogonyalovo) < the verb pogonyat', which can be used with the

1 The noun prozvishshe derives from the verb prozyvat', meaning 'to call, to name somebody informally'. In its turn, the verb prozyvat' is a derivative from a neutral verb zvat', meaning 'to call', which has two meanings: 1 ) 'to address somebody by a name, to use a particular name when talking to somebody'; 2) 'to shout or say somebody's name loudly to attract this person's attention.' 
following meanings: 1) 'to make animals (especially, a horse) run quicker by the sound of one's voice'; 2) 'to hurry somebody up'. Thus, the word reveals the humiliating nature of this type of nomination;

3) pozyvnoy (= a coded name as a call sign). This colloquial term discloses the conspiratorial, integrating, coding functions of nicknames;

4) pritsep (literally, 'a trailer') < the verb pritsepit', tseplyat' with the meaning 'cling, attach to something', which emphasizes the strong association (or link) of the name bearer and his/her informal nomination. Thus, metaphorically speaking, the nicknamed person has to bear this nomination as a burden that s/he cannot get rid of;

5) pogremukha < from the noun pogremushka ('a rattle', 'a baby's toy') + colloquial suffix -kha. Metaphorically, it can be associated with a cowbell that you cannot get rid of. It disturbs its bearer but entertains others.

The aforementioned chain of synonyms represent a case of metalinguistic profanity of the term prozvishshe itself, along with disclosing its inherent pragmatic potential and status within the anthroponymic system.

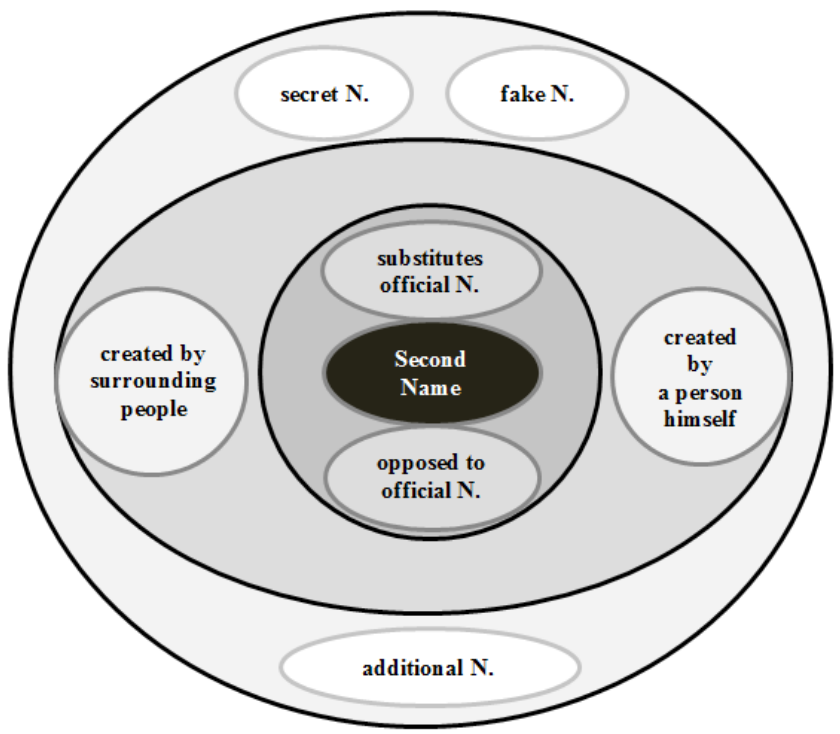

Figure 1. Prozvishshe represented as a concept

Thus, secondly, the subjects' responses shed light on the notion of nickname. Analyzing it, I took into consideration the following types of data, obtained from questionnaires: 1) definitions of the term prozvishshe, which respondents were asked to give, phrasing them intuitively; 2) the information respondents provided about the nicknames they listed in the main part of the questionnaire. As a result, prozvishshe is defined as a type of nomination, which: 
a) according to the object named, can refer to persons (the most frequent answer) as well as animals and any other animate or inanimate objects;

b) according to the status of nomination, is treated as a second name (the most frequent answer); substituting or opposing an official name; a non-official name; a fake name; an additional name; a direct address or, vice versa, a secret name/an antonym, given in order to conceal a real name; created by people surrounding you or by a person him/herself (e.g. an internet nick, a pseudonym).

The concept of 'prozvishshe' is represented in Figure 1 above, in which the distinctive features are distributed from the kernel to the periphery, depending on their frequency in the subjects' answers ("N." stands for 'name').

\section{The profane in the functions of nicknames}

\section{Familiarity and breaking hierarchy}

Familiarity is embedded in nicknames due to their status as informal nominations. Familiarity as the feature of the profane results in such functions of nicknames as establishing and expressing friendly relationships, integrating group members, distance shortening (among family, relatives, friends, colleagues). However, particularly profane are those nicknames which break the hierarchy, as they are bestowed regardless of status or rank of the nominee (no matter whether they are used directly or behind a bearer's back), thus violating the rules accepted in formal discourse. In particular, there occur cases of "top-down" nicknames, created by the powers that be or their teams in order to produce an impression (an illusion) of distance shortening and aimed at gaining popularity and acceptance among "common people" (e.g. the use of diminutives instead of official names of politicians in the USA and Great Britain: Bill Clinton, Tony Blair). In my opinion, "top-down" nicknames are not considered part of the profane culture due to the sphere in which they are created and their mostly honorific character.

As for nicknames, representing cases of "bottom-up" nomination (such as teachers' nicknames, bosses'/supervisors' nicknames, as well as nicknames of authorities, politicians etc.), they form the kernel of the profane among anthroponyms. The function of such nicknames as cases of collective mockery is to integrate the subordinates in order to cope with negative emotions and situations (e.g. feeling humiliated, irritated, dissatisfied, intimidated, deprived of rights etc.) and enjoy revenge by paying back disrespect and humiliation along with creating the illusion of having power over the objects you nickname. This phenomenon is akin to the category of carnival laughter, which unites common people and denies prohibitions and hierarchical order (Khalizev 2005: 85).

Needless to say that "bottom-up" nicknames are the most loaded in terms of their profaning potential.

\section{Evaluating through mockery, "crowning through decrowning"}

Furthermore, the following functions contribute to the profane in nicknames:

a) attitudinal: the subjects reported about nicknaming as a means of expressing 
attitude, personal perception, negative emotions towards the nominee, as well as a way to offend, humiliate, name negative qualities of the nickname bearer;

b) ludic: according to the subjects, nicknames are used to tease, entertain, express playfulness, humor. Thus, nicknames are given "for fun", but not always the nickname bearer's fun. The symbol of "crowning through decrowning" characterizes the nicknaming process in the following way: instead of "a crown of a name" a person has to wear "a fools' crown of a nickname", often against his/her wish;

d) evaluative, connected with expressing judgement and opinions about the nominee's qualities and attributes.

These functions directly affect connotative characteristics of nicknames. According to their connotation, nicknames in the collected sample of data fall into the following groups: jocular, neutral, positive, negative (see Figure 2). From the point of view of profaning functions, the first and the last groups are of interest to us. Thus, I excluded from my further analysis nicknames labelled by respondents as neutral or positive.

Further on, connotation is considered in connection with motivational types of nicknames.

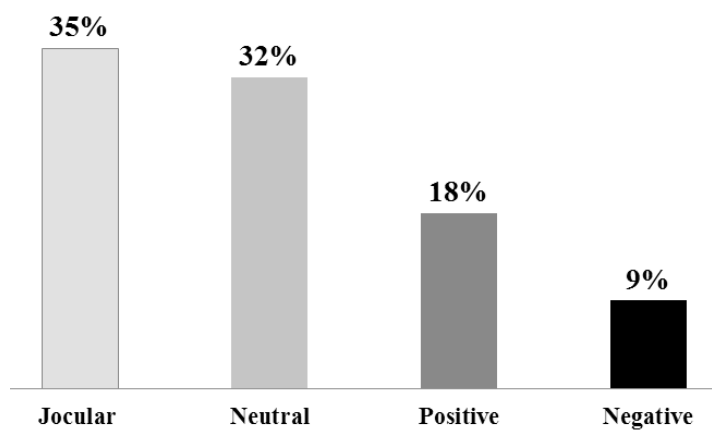

Figure 2. Connotation of nicknames in the collected sample of data (2014-2017)

\section{The profane in nicknames of different motivational types}

\section{Profaning linguistic and extralinguistic attributes of nickname bearers}

The two basic types of motivation - linguistic (non-characteristic) and extralinguistic (characteristic) - correspond to the two levels of profaning a nickname bearer:

a) By means of deforming the official name (linguistically motivated nicknames, $49.4 \%$ of all the nicknames listed in the questionnaires ${ }^{2}$ ). The essence of profanity is connected in this case with the idea of a unity between a person and his/her name. That is why no matter how serious the alterations of the name are, the "victims" of such nomination experiments can be quite sensitive about it.

2 Nicknames from questionnaires lacking explanation of their motivation were not considered for analysis. 
The most harmless results of the language games are surname shortenings, representing meaningless nicknames, labelled as either neutral or positive due to lack of inner form:

(1) Фpos [Frol] < surname Frolov (etymologically from the personal name Frol);

(2) $\mathrm{Ca}$ [Saz $]$ < surname Sazykina (meaningless shortening).

Thus, among linguistically motivated nicknames the profanities are coined by means of creating the wrong (or false) analogy of the nominee with the denotatum of the appellative used as a nickname. The wrong analogy is based on mockery at the name through reviving, "clarifying" or violating its possible etymology, simplifying it, barbarizing it by means of folk etymology or phonetic associations, rhymes:

(3) Борш [Borsh (Russian beetroot soup)] < surname Barysheva; labelled as jocular;

(4) Булка 1 [Bulka (a loaf of bread)] < surname Bulgakova; labelled as jocular;

(5) Аинозаврик [Dinozavrik (dinosaur + diminutive suffix)] < personal name Diana; labelled as jocular;

(6) Xopëк [Khoryok (polecat)] < rhyming with Igoryok (a diminutive from the first name Igor); labelled as jocular;

(7) Посудомойка [Posudomoyka (a dish-washer (a person)] < surname Sudomoykin (etymology: the one who does cleaning on board vessels: boats, ships); labelled as offensive, due to unfavorable associations with this type of job;

(8) Беркуm [Berkut (golden eagle)] < surname Sokolov (from the noun sokol 'falcon'; the nickname is based on the semantic association with the thematic group of birds of prey); labelled as jocular and friendly.

Moreover, among nicknames marked as jocular, there are alterations of personal names based on the phonetic association or analogy with a corresponding foreign personal name:

(9) Пэдро [Pedro] < first name Peter; labelled as jocular;

(10) Аıан $[$ Alan] < first name Alina (phonetic association of a Russian female name with the international male name); labelled as jocular;

(11) Аюдовик [Ludovic] < first name Lyudmila (phonetic association of a Russian female name with a famous French male name); labelled as jocular.

In examples (10) and (11) the jocular effect is strengthened by the play on the gender of the names and nominees.

b) By means of mockery at the nominee's properties (45.5\% of all nicknames analyzed). According to our sample of data, the following qualities are profaned:

Table 5. Qualities profaned by means of characteristic nicknames

\begin{tabular}{|l|c|l|}
\hline Qualities profaned & $\%$ & Examples \\
\hline Appearance & 34.7 & $\begin{array}{l}\text { (12) Xomabolu }[\text { Khottabych] < appearance (allusion to the } \\
\text { Old Genie Khottabych, a famous character from the Soviet } \\
\text { children's book and film); labelled as jocular; }\end{array}$ \\
\hline
\end{tabular}




\begin{tabular}{|c|c|c|}
\hline Qualities profaned & $\%$ & Examples \\
\hline & & $\begin{array}{l}\text { (13) Bieber < resemblance; labelled as jocular; } \\
\text { (14) Unasa [Shpala (railway tie)] < tall; labelled as jocular; } \\
\text { (15) Blondie, Red, Slender, Shortie, Curlie } \text {; labelled as jocular }\end{array}$ \\
\hline Character and behavior & 29.9 & $\begin{array}{l}\text { (16) Курииа [Kuritsa (hen)] < too talkative; labelled as of- } \\
\text { fensive; } \\
\text { (17) Кıоун }[\text { Clown] < always smiles; labelled as jocular; } \\
\text { (18) Сернал кислота }[\text { Sulfuric acid] < active and cheerful } \\
\text { person; labelled as jocular }\end{array}$ \\
\hline Situation & 12.5 & $\begin{array}{l}\text { (19) Булка [Bulka (loaf)] < gave up a fitness center (a loaf } \\
\text { of bread is associated with a lazy lifestyle and being over- } \\
\text { weight); labelled as offensive }\end{array}$ \\
\hline $\begin{array}{l}\text { Gastronomic prefer- } \\
\text { ences }\end{array}$ & 2.6 & $\begin{array}{l}\text { (20) Pelmeshka }{ }_{1} \text { [Russian ravioli], Syrok [Curd cake/ Cheese } \\
\text { cake], Snickers < a person's gastronomic preferences; labelled } \\
\text { as jocular; }\end{array}$ \\
\hline Speech & 2.6 & $\begin{array}{l}\text { (21) Kapmaвыı̆ [Kartaviy] < speech defect (pronouncing } \\
\text { the Russian /r/ with a burr); labelled as jocular }\end{array}$ \\
\hline Clothes & 2.6 & $\begin{array}{l}\text { (22) Плтачок }[\text { Piglet }]<\text { wears pink clothes; labelled as } \\
\text { jocular; } \\
(23) \text { Слива }[\text { Sliva (plum) }]<\text { plum color of a shirt; labelled } \\
\text { as jocular }\end{array}$ \\
\hline $\begin{array}{l}\text { Intellectual abilities } \\
\text { (strengths) }\end{array}$ & 1.1 & 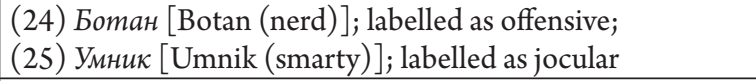 \\
\hline Appearance + character & 1.1 & $\begin{array}{l}\text { (26) Жаба }[\text { Zhaba (toad) }]<\text { mixed motivation, based on } \\
\text { the teacher's character and appearance; labelled as offensive; } \\
\text { (27) Воробей [Vorobey (sparrow)] < mixed motivation: a } \\
\text { talkative person, resembling a sparrow; labelled as jocular }\end{array}$ \\
\hline
\end{tabular}

1 Descriptive nominations translated from Russian into English.

The table does not include the groups of nicknames in which neutral or positive nominations prevail (occupation, preferences, age, physical abilities (strengths), hobbies, nationality, health issues). These groups are also the least numerous, along with the group "intellectual disabilities", represented by only one nickname in our sample of data (labelled as offensive).

c) By means of violating both the name and the qualities (mixed motivation, $1.2 \%)$ :

(28) Кисльй [Kisly (sour)] < surname Kislyakov + character and behavior; labelled as negative;

(29) Немец [Nemets (a German)] < surname Neelmeyer + nationality; labelled as jocular.

Table 6 below shows the distribution of non-characteristic (linguistically motivated) and characteristic (extralinguistically motivated) nicknames according to their connotation. Peculiar is the fact that, though the ratio of jocular nicknames is almost 
equal in both groups, the amount of nicknames suggesting negative characteristics significantly exceeds the amount of nicknames in the group of non-characteristic nicknames. This difference proves the fact that the profane is primarily expressed primarily in characteristic nicknames.

Table 6. Profane connotation of nicknames depending on motivation type (\%)

\begin{tabular}{|l|c|c|c|c|}
\hline Type of nickname & Jocular & $\begin{array}{c}\text { Negative } \\
\text { (pejorative) }\end{array}$ & Mixed & $\begin{array}{c}\text { Others } \\
\text { (positive, } \\
\text { neutral) }\end{array}$ \\
\hline Non-characteristic (from a personal name) & 31 & 4 & 4 & 61 \\
\hline Characteristic & 32 & 14 & 6 & 48 \\
\hline Non-characteristic (from an appellative) ${ }^{1}$ & & 34.8 & & 65.2 \\
\hline
\end{tabular}

1 Here belong purely pejorative nominations, based on derogatory appellatives (1.3\%, e.g. Stinky, Dummy) or pure pet names/love names used as terms of endearment (2.5\%, e.g. Hare, Doughnut, Kitten).

\section{Revealing secret/hidden/sacred meaning}

Profanities as part of carnival culture aim at disclosing the secret (hidden, sacred) meaning of things, clarifying, explaining the essence of things, depicting down-toearth, material world (Literary Encyclopedic Dictionary 1987: 150-152).

This aspect of the profane is featured in nicknames through

1) attempts to give meaningful names by means of characterizing a person or reviving etymology (or false etymology) of his/her official name (see examples 3-8 above);

2) pointing out primarily physical characteristics of a person (the frequency of such nicknames is considered their universal feature); nicknames.

3) using appellatives denoting objects of the material world as sources of

Basic mechanisms are those allowing to disclose a person's qualities by linking them with the material world and material objects (or the objects which can be easily visualized) by means of:

a) metonymy (establishing a link between the two objects based on their material juxtaposition):

(30) Lob [Forehead] < high forehead (labelled as offensive); Glaza [Eyes] < big eyes (labelled as offensive);

(31) Romashka [Chamomile] < a child had a pacifier in the shape of this flower (labelled as offensive);

(32) Baklazhan [Aubergine/Eggplant] < 1) a person sang a song about this vegetable; 2 ) a tall person (labelled as jocular);

b) metaphor (establishing an association of similarity between the two objects and their qualities):

(33) Pelmeshka ${ }_{2}$ [Russian ravioli] a person is overweight (labelled as jocular);

(34) Kisa [Pussy] < a person ate Whiskas (labelled as offensive); 
(35) Valyet [Jack/knave] < a person resembles this playing card character (labelled as offensive);

(36) Poltorashka [colloq. A liter and a half plastic bottle] < a person is $157 \mathrm{~cm}$ tall (labelled as jocular);

(37) Hulk < a stout person (labelled as jocular);

(38) Stremyanka [Ladder] < a person is very tall (labelled as jocular);

(39) Panda < a person had mascara marks under her eyes (labelled as jocular);

(40) Tsygan [Gypsy] < complexion (labelled as jocular);

(41) Morkovka [Carrot] < hair color (labelled as jocular);

c) paronomasia:

(42) Центнер [Center] < surname Zelmer (labelled as offensive).

\section{Exaggerating/denying/contradicting reality, turning it upside down by means of the grotesque}

Exaggeration, contrast to reality, contradiction with reality, going against the truth, turning it upside down according to the properties of the profane correspond to the idea of distorting reality, which is often found in nicknames.

As a result, nicknames can create a grotesque image of a person by means of hyperbole, irony, pun (paronomasia, false etymology of a personal name), each of which deal with faking reality.

Exaggeration as the form of distorting reality finds its expression in nicknames highlighting a certain quality and magnifying it. Used as a motive for an alternative name, this quality dominates other qualities and provokes stereotypes and generalizations about a personality as such. From this perspective all nicknames mentioned above can be found "guilty of slander" to a certain degree, even those which directly name the quality (descriptive and metonymic nicknames). At its extreme, exaggeration can lead to a discrepancy between the real qualities of a person and qualities implied by a nickname.

Contradiction with reality, going against the truth and turning the real state of things upside down can be found in characteristic nicknames based on irony (Dragon $<$ a small and shy boy) and non-characteristic nicknames based on a personal name or surname, especially those representing the cases of folk etymology or arbitrary phonetic associations (see examples 3-8 above).

\section{Profaning nickname givers and nickname users (self-profaning)}

Finally, the subjects reported about the function of self-expression of nickname givers, which is connected with gaining popularity in the group by showing off as a creative and witty person.

However, though profanities are directed at a nickname bearer, nicknames can backfire on the nickname givers and users as well. In this case profaning, like a boomerang, can play against the profaner. Thus, the phenomenon of self-profaning (selfdecrowning, self-discrediting) can be observed, indirectly disclosing the nickname 
giver's characteristics (e.g. using taboo words in nicknaming or choosing the motives to which it is politically incorrect to refer).

\section{Conclusion}

1. All nicknames "commit a nomination crime" as long as they parody, mock or violate the established nomination rules, which all do due to their unconventional status within the anthroponymic system.

2. The potential to profane in nicknames depends on the functional, connotative and motivational types of nicknames. According to the ratio of jocular vs negative nicknames, the following scale was made, demonstrating the dynamics of nicknames and their potential to function as profanities (see Figure 3).

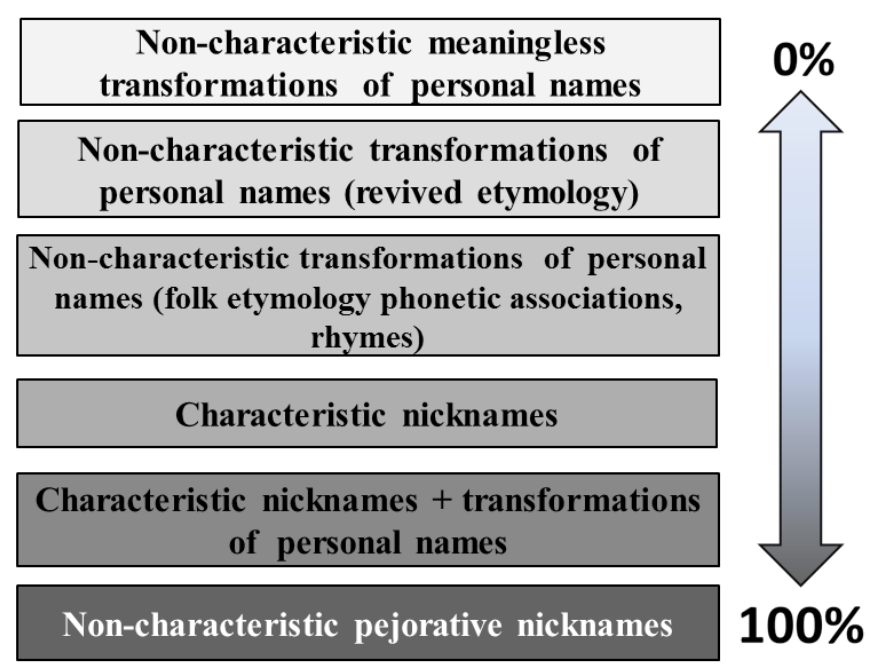

Figure 3. Scale of non-profane to profane nicknames (depending on the type of motivation)

3. Taking into account the triangle paradigm "function - connotation - motivation", one can see that not all nicknames "boast" possessing the profaning potential: hypocoristics, honorifics, pet names, love names, terms of endearment are not considered as such due to their positive connotation, though they still represent digression from the official naming patterns.

4. Among nicknames related to the category of the profane, meaningless transformations are the least marked and this is the smallest group in the selected subsample (9\%). Most such nicknames are labelled as neutral and, strictly speaking, not considered as profanities.

5. The degree of profaning grows according to the scale, reflecting the principle mentioned above. Thus, the profaning potential grows together with characterizing 
potential from non-characteristic but meaningful nicknames to nicknames profaning both linguistic and extralinguistic attributes of a person.

6. The three biggest groups of characteristic nicknames treated as profane due to their connotation are those based on appearance (highest profaning potential judging by the number of offensive nicknames), character/behavior and situation.

7. In our opinion the highest degree of profanity is expressed in non-characteristic nicknames, derived from pejorative appellatives, as their aim is purely to offend, without any objective reason.

\section{References}

Bakhtin, M.M. 1990. Rabelais and Folk Culture of the Middle Ages and Renaissance (in Russian). Moscow: Khudozhestvennaya literatura.

Cambridge Dictionary.org. http://dictionary.cambridge.org/dictionary/english/profanity (accessed August 20,2017).

Chernobrov, A.A. 2006. Linguoculturology: Basis of Integral Humanitarian Knowledge (in Russian). Novosibirsk: Svinyin and Sons.

Felecan, D. 2009. Nicknames - Reflections of Polyphony within the Linguistic Area from the Northwestern Part of Romania. "Nomina Africana", Journal of the Names Society of Southern Africa 23 (2): 61-89.

Felecan, O. 2014. A Psycholinguistic Approach to Nicknaming (With Reference to Nicknames Given by Students to Teachers). In Names and Their Environment. Proceedings of the 25th International Congress of Onomastic Sciences Glasgow 25-29 August 2014: Vol. 3, C. Hough and D. Izdebska (eds.), 65-81. Glasgow: University of Glasgow.

Hunt, M. 2008. Christianity and Literature. Book Reviews. In The Sacred and Profane in English Renaissance Literature, 175-178. University of Delaware Press.

Khalizev, V.E. 2005. Theory of Literature (in Russian). Moscow: Vysshaya Shkola.

Klerk, V. de and B. Bosch. 1997. Nicknames of English Adolescents in South Africa. Names. A Journal of Onomastics 45 (2): 101-118.

Likhachev, D.S, A.M. Panchenko and N.V. Ponyrko. 1984. The Laughter World of Early Russia (in Russian). Leningrad: Nauka.

Literary Encyclopedic Dictionary (in Russian). 1987. Moscow: Sovyetskaya encyclopedia.

Merriam-Webster.com. https://www.merriam-webster.com/dictionary/profane (accessed August 20, 2017).

Morgan, J., C. O’Neill and R. Harre. 1979. Nicknames: Their Origins and Social Consequences. London, Boston and Henley: Routledge and Kegan Paul.

Oxford Learner's Dictionaries.com. http://www.oxfordlearnersdictionaries.com/definition/english/profane_1?q=profane (accessed August 20, 2017).

Podolskaya, N.V. 1988 . The Dictionary of Russian Onomastic Terminology (in Russian). Moscow: Hauka.

Ross, A. 2013. The Problem of the Image: Sacred and Profane Spaces in Walter Benjamin's Early Writing. Critical Horizons 14 (3): 355-379.

Ushakov, N.N. 1978. Nicknames and Personal Unofficial Names (Concerning the Nickname Borderline). In Common and Proper Name, 146-173. Moscow. 